\title{
SEACRAFT HULLS PROTECTION WITH Ti, Cu - BIOCIDE PIGMENTS
}

\author{
${ }^{1}$ V. A. Shablovski, ${ }^{1}$ A. V. Tuchkovskaya, ${ }^{1}$ V. A. Rukhlya, ${ }^{1}$ O. G. Pap, ${ }^{2} * S$. L. Vasilyuk
}

${ }^{1}$ Laboratory of inorganic sorbents and anticorrosive coatings, Research Institute for Physical Chemical Problems of the Belarusian State University, Minsk, 220006, Belarus.

${ }^{2}$ Special engineering bureau, Institute of General and Inorganic Chemistry NAS Ukraine, Kyiv, 03142, Ukraine.

*Corresponding author: vasiluk@ionc.kiev.ua

\begin{abstract}
The main directions of creating new forms of anti-fouling coatings for hulls of sea vessels lie in the field of obtaining an optimal biocide or mixture of biocides. Copper (I) oxide and copper-containing compounds are currently used as the main biocide in such compositions. To obtain competitive biocides containing copper (I) oxide, it is necessary to use relatively cheap inert fillers. The authors proposed a method for producing pigments based on titanium (IV) phosphate and copper compounds that have toxic effect on marine microorganisms for use in coatings that prevent biofouling of ship hulls in seawater. It is shown that by varying the initial ratio of $\mathrm{Cu}$ (II) : Ti (III) in the composition of the pigment, the order of mixing, and the temperature of heat treatment of the pigment, it is possible to change the content of various copper compounds in the polymer matrix of titanium phosphate. The obtained samples were studied using the X-ray diffraction, differential scanning calorimetry, scanning electron microscopy methods and other. Thermal transformations of titanium (IV) phosphate samples containing copper in different oxidation states were studied by thermal synchronic analysis in air and nitrogen.

The conditions for obtaining a pigment with a maximum content of copper (I) oxide, necessary for prolonged inhibition of fouling, were found. The ability of the compositions to leach copper and phosphate ions in distilled water and in water similar in composition to seawater, depending on the conditions of heat treatment, was studied. Evaluation tests of the biocidal activity of the obtained pigments in relation to ciliates Tetrachimena piriformis and test cultures of bacteria Staphylococcus aureus, Bacillus subtilis were carried out.
\end{abstract}

Key words: antifouling pigments; biocidal properties; titanium phosphate; copper (I) and (II) compounds. 


\section{Introduction}

To protect the hulls of ships from fouling, special anti-fouling materials containing toxic components are used. The effect of anti-fouling coatings is that during operation they gradually dissolve, and their toxic components prevent the attachment of organisms to the hull skin or kill them. Compounds of copper, mercury, zinc, arsenic, tin, lead, and some organic compounds are used as toxins [Railkin, 1998; Gurevich et. al., 1989; Sheshukov et. al., 1992; Kopylov, 2011]. The solubility of toxins should provide concentration in the layer of water in contact with the treated surface of the hull to be sufficient to protect the hull from fouling.

The mechanism of the protective action of anti-fouling coatings is based on the leaching of the biocide (pigment). Leaching is the process of dissolving (washing out) soluble components from a protective coating. The effectiveness of the anti-fouling composition is proportional to the biocide content of the coating. For each biocide, there is a critical leaching level where the biocide remaining in the film no longer provides antifouling protection. The rate of leaching of the biocide is also affected by the thickness of the coating layer [Zobachev, 1984]. Traditionally, anti-fouling materials are produced mainly on vinyl and chlorinated rubber bases, as well as rosin. Compounds containing lead, mercury, arsenic and tin were previously used as biocides in them, which are currently prohibited for use. Examples of such coatings are presented in patents [Gurevich, 1983; Karpov, 2010; ZAO «HIMEKO-GANG», 1998; Braeken et. al., 1990; Matsuo, 1990; Camp, 2004]. The main directions of creating new forms of antifouling coatings lie in the field of obtaining an optimal biocide or a mixture of biocides and creating a carrier with a controlled release of biocides for five or more years. Only the most potent biocides are suitable for this purpose. Copper (I) oxide and other copper-containing compounds are currently used as the main biocide in such compositions [Baxter, 1987]. Copper (I) oxide has a solubility value of $5.4 \mu \mathrm{g} / \mathrm{cm}^{3}$ in seawater at $\mathrm{pH} 8.1$, which ensures a long-term transfer of this biocide into seawater with a concentration that is lethal to marine organisms. This solubility of copper (I) oxide in seawater is achieved after an induction period, which, depending on the ambient temperature and $\mathrm{pH}$ of seawater, can last up to 3 months.

One of the main organic polymers used to obtain antifouling coatings with copper (I) oxide is rosin [Baxter, 1987; Beznosov et. al. 2013]. The mechanism of action of such a coating is based on the solid-phase reaction of copper oxide with rosin to form copper resinates, readily soluble in seawater, which then interact with chlorides dissolved in seawater, forming toxic compounds. In addition to rosin, the coating may include organic hydroxy acids, organic acid anilides, mineral pigments, plasticizers and organic solvents. Salicylic, tartaric, malic acids are used as organic hydroxy acids in the proposed compositions, and dibutyl phthalate, tricresyl phosphate, 
polyisobutylene are used as plasticizers; zinc oxide, iron minium are used as mineral pigments; copper monoxide, cupric rhodanide are used as copper-containing biocides; organic solvents solvent, xylene, petroleum spirit. Also known are compositions that include, in addition to the above components, polymeric film-formers - a copolymer of vinyl chloride with vinyl acetate, epoxy resin and epoxy ester varnish, as organic solvents - acetone, cyclohexanone, etc. [Karpov, 2010; Beznosov, 2013].

To obtain competitive pigments containing $\mathrm{Cu}(\mathrm{I})$, it is necessary to use relatively cheap inert fillers. As such a filler, we have chosen previously not used for these purposes X-ray amorphous titanium phosphate $\mathrm{Ti}\left(\mathrm{HPO}_{4}\right)_{2} \cdot n \mathrm{H}_{2} \mathrm{O}$, the synthesis of which in a solution of phosphoric acid, sorption properties and chemical stability are well known [Maslova, 2006; Shablovski, 1983]. This particular filler was chosen for several reasons. Firstly, this material is known to be a good anticorrosive pigment, which is widely used in world practice. Secondly, as it is known, the world accumulates sufficiently large amounts of titanium metal waste, which cannot be recycled by traditional metallurgical methods, but is easily converted into salts of this metal. In this regard, it is promising to use waste metal titanium as a cheap source of trivalent and tetravalent titanium compounds for the production of cheap pigments based on titanium phosphate.

The aim of this work is to develop a method for producing a pigment based on titanium phosphate with high content of copper oxide and to prove the possibility of its use in antifouling compositions.

\section{Materials and Methods}

Trivalent titanium phosphate was obtained by dissolving titanium metal in $20 \%$ orthophosphoric acid at $105^{\circ} \mathrm{C}$ for $4 \mathrm{~h}$ in the presence of a catalyst according to our method [Shablovski, 1983]. In this work, the interaction of $\mathrm{CuCl}_{2} \cdot 2 \mathrm{H}_{2} \mathrm{O}$ with $\mathrm{TiPO}_{4}$ was studied in various molar ratios. It was assumed that $\mathrm{Ti}$ (III) would exhibit reducing properties and the pigment would thus include cuprous compounds in a tetravalent titanium phosphate matrix. To obtain a pigment of the required composition, the $\mathrm{Cu}$ (II) : Ti (III) ratio, the order of mixing the components, and the drying modes of the obtained samples were varied during the synthesis. Samples were prepared by mixing under normal conditions $1 \mathrm{M}$ solutions of $\mathrm{CuCl}_{2}$ and $\mathrm{TiPO}_{4}$ at a molar ratio of copper to titanium from $1: 2$ to $1: 5$. The resulting solutions were stirred with a magnetic stirrer for $25 \mathrm{~min}$. The precipitate was separated from the solution by decantation, filtered on a Buchner funnel, and dried at $70-$ $80^{\circ} \mathrm{C}$. The resulting pigment samples were heated in air at temperatures of 160,215 , and $260{ }^{\circ} \mathrm{C}$. X-ray diffraction studies of the obtained samples were performed using a DRON-3.0 diffractometer (CoK $K_{\alpha}$-radiation, Mn-filter). The recording speed in the angular range $2 \theta=3-60^{\circ}$ was $1 \mathrm{deg} / \mathrm{min}$. To decode the X-ray diffraction patterns and obtain the quantitative characteristics of the obtained compounds, the data were entered into a special computer program MATH, based on the PDF-2 X- 
ray diffraction databases of the ICCD company. The content of the components (\%) was determined using reference intensity ratio of the maximum peaks characteristic for the isolated phases.

Thermal analysis of the samples was carried out by differential scanning calorimetry on an STA 449 C Jupiter synchronic thermal analyzer (NETZSCH, Germany) in air and in nitrogen atmosphere.

The morphology of pigment powders was studied by scanning electron microscopy (SEM, microscope LEO-1420). X-ray energy dispersive microanalysis was performed on the same instrument with a Roentec attachment.

Leaching of copper ions and phosphate ions was carried out in distilled water and in a solution imitating seawater of the composition $\left(\mathrm{g} / \mathrm{dm}^{3}\right)$ : $\mathrm{NaCl}-10.0 ; \mathrm{MgSO}_{4}-1.0$ according to the following method. Pigment samples weighing $100.0 \mathrm{mg}$ were placed in $10.0 \mathrm{~cm}^{3}$ of distilled water or a solution of simulated seawater, kept for 7 days, after which the content of copper ions and orthophosphate ions in the settled solutions was analyzed. The $\mathrm{pH}$ of the resulting solutions was determined using an I-160MP laboratory ionomer. The arithmetic mean of the results of three parallel determinations, the difference between which did not exceed $0.1 \mathrm{pH}$ units, was taken as the test result.

The determination of copper was carried out on an atomic emission spectrometer with inductively coupled plasma "ACTIVIA M" (France).

The phosphorus content was determined by the colorimetric method by the yellow color of the phosphorus vanadate-molybdate complex on a KFK-3-01 photoelectric photometer at $\lambda=460 \mathrm{~nm}$.

The toxicity of the test samples was determined according to the "Methodological Guidelines for the Toxic-Biological Evaluation of Meat, Meat Products and Milk Using Tetrachimena Piriformis Ciliates" by the presence of dead and surviving ciliates, changes in the shape and growth inhibition of Tetrachimena piriformis at the S. N. Vyshelesskiy Institute of Experimental Veterinary Medicine of NAS Belarus according to the following method. A certain amount of pigments was added to tubes containing a nutrient medium and a certain number of ciliates, shaken thoroughly, and left at room temperature for 24 hours in a dark place. During the day, the test tubes were shaken 3-4 times in order to aerate the medium and stir up the settled particles of the test material. After 1, 6, 24, and 96 hours, inoculation samples from each tube were examined under an optical microscope. The presence of dead or deformed cells, deceleration and change in the nature of movement, inhibition of the growth and reproduction of ciliates in comparison with the control indicated the toxicity of the test material. Evaluation of toxicity in relation to ciliates Tetrachimena piriformis was carried out on a 4-point system. A decrease in the degree of reproduction of protozoa by $20-30 \%$ indicated the presence of weak toxicity ( 1 point). The suppression of reproduction of ciliates up to $30 \%$ with a simultaneous decrease in movement activity, violation of its character and the presence of up to $10 \%$ of altered cells indicated a moderate degree of toxicity ( 2 points). Decrease in the degree of reproduction of ciliates by $30-50 \%$ with the simultaneous presence of $10-20 \%$ of cells with 
disturbances in the nature of movement, shape and dead ciliates indicated the expressed toxicity of the product ( 3 points). And, finally, a decrease in the degree of reproduction of ciliates by $50 \%$ and more, the presence of cysts, deformed cells (in particular in the form of drumsticks, etc.) indicates a strong toxicity of the product (4 points).

In the same place, the biocidal (antimicrobial) activity was rated by the method of serial dilutions in relation to test cultures of bacteria Staphylococcus aureus, Bacillus subtilis. The resistance of test microbes of bacteria Staphylococcus aureus, Bacillus subtilis to the obtained samples was studied by diffusion into agar using wells in the thickness of the agar (bacteriostatic activity). The presence of a zone of inhibition of microbial growth around the wells and its size were indicators of the sensitivity of the test culture to the test samples.

\section{Results and discussion}

Table 1 shows the phase composition of copper compounds in the composition of pigments obtained at different molar ratios of $\mathrm{Cu}$ (II) : Ti (III) in the initial solutions and temperatures of heat treatment. As can be seen from the table, the transformation products of copper compounds are $\mathrm{Cu}$, $\mathrm{Cu}_{2} \mathrm{O}, \mathrm{CuO}, \mathrm{CuCl}, \mathrm{Cu}_{2}(\mathrm{OH})_{3} \mathrm{Cl}, \mathrm{Cu}_{2} \mathrm{Cl}(\mathrm{OH})_{3}$, etc.

Studies have shown that, because of redox reactions in the $\mathrm{CuCl}_{2} \cdot 2 \mathrm{H}_{2} \mathrm{O}: \mathrm{TiPO}_{4}$ system, $\mathrm{Cu}$ (II) is reduced to $\mathrm{Cu}(\mathrm{I})$ and $\mathrm{Cu}(0)$. A diagram of the ongoing processes can be represented in the form of equations:

$$
\begin{gathered}
\mathrm{Ti}^{3+} \mathrm{PO}_{4}+\mathrm{Cu}^{2+} \rightarrow \mathrm{Ti}^{4+}\left(\mathrm{HPO}_{4}\right) \cdot n \mathrm{H}_{2} \mathrm{O}+\mathrm{Cu}^{0}+\mathrm{Cu}^{+} \\
\mathrm{Cu}^{0}+\mathrm{O}_{2} \stackrel{150-250^{\circ} \mathrm{C}}{>}>\mathrm{Cu}_{2} \mathrm{O}
\end{gathered}
$$

In the case of the $\mathrm{Cu}$ (II) : $\mathrm{Ti}$ (III) ratio 1: 2, copper (I) compounds are not formed in the entire tested temperature range. As the ratio increases from $1: 3$ to $1: 4.5$, the amount of $\mathrm{Cu}_{2} \mathrm{O}$ increases. The highest content of $\mathrm{Cu}_{2} \mathrm{O}(56.4 \%)$ was noted at the $\mathrm{Cu}$ (II) : Ti (III) ratio $1: 4.5$ (sample \#5). When studying the dependence of the amount of $\mathrm{Cu}_{2} \mathrm{O}$ on the processing temperature, it was found that with an increase in the specified ratio from $1: 3.5$ to $1: 4.5$, the content of $\mathrm{Cu}_{2} \mathrm{O}$ in the samples increases to $99.6 \%$.

It was determined [Shablovski, 1983] that titanium in the pigments obtained is in the form of titanium (IV) hydrophosphate $\mathrm{Ti}\left(\mathrm{HPO}_{4}\right)_{2} \cdot n \mathrm{H}_{2} \mathrm{O}$ crystalline hydrate, which is formed as a result of oxidation of Ti (III) phosphate to Ti (IV). According to the literature [Sarawadekar, 1983], crystalline hydrate $\mathrm{Ti}\left(\mathrm{HPO}_{4}\right)_{2} \cdot n \mathrm{H}_{2} \mathrm{O}$ is X-ray amorphous up to $600{ }^{\circ} \mathrm{C}$ and loses water of crystallization at $160{ }^{\circ} \mathrm{C}$, which is confirmed by the results of the X-ray phase analysis. We did not observe the diffraction peaks of titanium compounds in the X-ray diffraction patterns of samples 1-6 obtained by us both before and after heating. As an example, Fig. 1 shows a line X-ray diffraction pattern of sample \#5, obtained at room temperature, from which it follows that only crystalline phases of copper compounds are present in the pigment samples. 
All the samples obtained were studied by the method of synchronic thermal analysis when heated to $800{ }^{\circ} \mathrm{C}$.

Table 1. Phase composition of copper compounds depending on the $\mathrm{Cu}$ (II) : $\mathrm{Ti}$ (III) ratio and air heat treatment temperatures

\begin{tabular}{|c|c|c|c|}
\hline $\begin{array}{c}\text { Sample } \\
(\mathrm{Cu}(\mathrm{II}): \mathrm{Ti}(\mathrm{III}) \text { ratio) }\end{array}$ & Temperature, ${ }^{\circ} \mathrm{C}$ & Phase composition & $\begin{array}{c}\text { Content of } \\
\text { components, \% }\end{array}$ \\
\hline 1 & 2 & 3 & 4 \\
\hline \multirow{7}{*}{$\begin{array}{c}\text { № } 1 \\
(1: 2)\end{array}$} & \multirow{2}{*}{20} & $\mathrm{Cu}_{2}(\mathrm{OH})_{3} \mathrm{Cl}$ & 54.1 \\
\hline & & $\mathrm{Cu}_{2} \mathrm{Cl}(\mathrm{OH})_{3}$ & 45.9 \\
\hline & \multirow{3}{*}{160} & $\mathrm{Cu}_{2} \mathrm{Cl}(\mathrm{OH})_{3}$ & 49.3 \\
\hline & & $\mathrm{Cu}_{2}(\mathrm{OH})_{3} \mathrm{Cl}$ & 30.3 \\
\hline & & $\left(\mathrm{CuCl}_{2}\right)\left(\mathrm{Cu}(\mathrm{OH})_{2}\right)_{3}$ & 20.4 \\
\hline & \multirow{2}{*}{260} & $\mathrm{Cu}_{2} \mathrm{Cl}(\mathrm{OH})_{3}$ & 90.4 \\
\hline & & $\mathrm{CuO}$ & 9.6 \\
\hline \multirow{13}{*}{$\begin{array}{c}\text { № } 2 \\
(1: 3)\end{array}$} & \multirow{3}{*}{20} & $\mathrm{Cu}_{2} \mathrm{O}$ & 13.3 \\
\hline & & $\mathrm{CuCl}$ & 61.8 \\
\hline & & $\mathrm{Cu}$ & 24.9 \\
\hline & \multirow{4}{*}{160} & $\mathrm{Cu}_{2} \mathrm{Cl}(\mathrm{OH})_{3}$ & 33.6 \\
\hline & & $\mathrm{Cu}_{2} \mathrm{O}$ & 32.2 \\
\hline & & $\mathrm{CuCl}$ & 14.3 \\
\hline & & $\mathrm{Cu}$ & 19.9 \\
\hline & \multirow{4}{*}{215} & $\mathrm{Cu}(\mathrm{OH})_{2}$ & 19.7 \\
\hline & & $\mathrm{CuO}$ & 32.4 \\
\hline & & $\mathrm{CuCl}_{2}\left(\mathrm{Cu}(\mathrm{OH})_{2}\right)_{3}$ & 30.5 \\
\hline & & $\mathrm{CuCl}$ & 17.4 \\
\hline & \multirow{2}{*}{260} & $\mathrm{Cu}_{2} \mathrm{Cl}(\mathrm{OH})_{3}$ & 51.9 \\
\hline & & $\mathrm{CuO}$ & 48.1 \\
\hline \multirow{9}{*}{$\begin{array}{c}\text { № } 3 \\
(1: 3.5)\end{array}$} & \multirow{2}{*}{20} & $\mathrm{Cu}_{2} \mathrm{O}$ & 3.8 \\
\hline & & $\mathrm{Cu}$ & 96.2 \\
\hline & 160 & $\mathrm{Cu}_{2} \mathrm{O}$ & 7.3 \\
\hline & & $\mathrm{Cu}$ & 92.7 \\
\hline & \multirow{2}{*}{215} & $\mathrm{Cu}_{2} \mathrm{O}$ & 25.5 \\
\hline & & $\mathrm{Cu}$ & 74.5 \\
\hline & \multirow{3}{*}{260} & $\mathrm{Cu}_{2} \mathrm{O}$ & 70.9 \\
\hline & & $\mathrm{CuO}$ & 21.6 \\
\hline & & $\mathrm{Cu}$ & 7.5 \\
\hline \multirow{9}{*}{$\begin{array}{c}\text { № } 4 \\
(1: 4)\end{array}$} & \multirow{2}{*}{20} & $\mathrm{Cu}_{2} \mathrm{O}$ & 4.5 \\
\hline & & $\mathrm{Cu}$ & 95.5 \\
\hline & \multirow{2}{*}{160} & $\mathrm{Cu}_{2} \mathrm{O}$ & 5.7 \\
\hline & & $\mathrm{Cu}$ & 94.3 \\
\hline & \multirow{2}{*}{215} & $\mathrm{Cu}_{2} \mathrm{O}$ & 21.1 \\
\hline & & $\mathrm{Cu}$ & 78.9 \\
\hline & \multirow{3}{*}{260} & $\mathrm{Cu}_{2} \mathrm{O}$ & 58.2 \\
\hline & & $\mathrm{CuO}$ & 30.7 \\
\hline & & $\mathrm{Cu}$ & 11.0 \\
\hline
\end{tabular}


Table 1. Phase composition of copper compounds depending on the $\mathrm{Cu}$ (II) : $\mathrm{Ti}$ (III) ratio and air heat treatment temperatures (continuation)

\begin{tabular}{|c|c|c|c|}
\hline \multirow{8}{*}{$\begin{array}{c}\text { № } 5 \\
(1: 4.5)\end{array}$} & \multirow{2}{*}{20} & $\mathrm{Cu}_{2} \mathrm{O}$ & 56.4 \\
\hline & & $\mathrm{Cu}$ & 43.6 \\
\hline & \multirow{2}{*}{160} & $\mathrm{Cu}_{2} \mathrm{O}$ & 60.5 \\
\hline & & $\mathrm{Cu}$ & 39.5 \\
\hline & \multirow{2}{*}{215} & $\mathrm{Cu}_{2} \mathrm{O}$ & 81.4 \\
\hline & & $\mathrm{Cu}$ & 18.6 \\
\hline & \multirow{2}{*}{260} & $\mathrm{Cu}_{2} \mathrm{O}$ & 99.6 \\
\hline & & $\mathrm{CuO}$ & 0.4 \\
\hline \multirow{9}{*}{$\begin{array}{c}\text { № } 6 \\
(1: 5)\end{array}$} & \multirow{2}{*}{20} & $\mathrm{Cu}_{2} \mathrm{O}$ & 52.3 \\
\hline & & $\mathrm{Cu}$ & 47.7 \\
\hline & \multirow{2}{*}{160} & $\mathrm{Cu}_{2} \mathrm{O}$ & 60.3 \\
\hline & & $\mathrm{Cu}$ & 39.7 \\
\hline & \multirow{2}{*}{215} & $\mathrm{Cu}_{2} \mathrm{O}$ & 78.8 \\
\hline & & $\mathrm{Cu}$ & 21.2 \\
\hline & \multirow{3}{*}{260} & $\mathrm{CuO}$ & 44.1 \\
\hline & & $\mathrm{Cu}_{2} \mathrm{O}$ & 28.9 \\
\hline & & $\mathrm{Cu}$ & 27.0 \\
\hline
\end{tabular}

Fig. 2 presents the data of thermal analysis of the dried, but unheated pigment (\#5), obtained at the $\mathrm{Cu}$ (II) : $\mathrm{Ti}$ (III) ratio $1: 4.5$, which, according to the data in table 1 , ensures the formation of $\mathrm{Cu}$ (I) compounds in the maximum amount in air atmosphere.

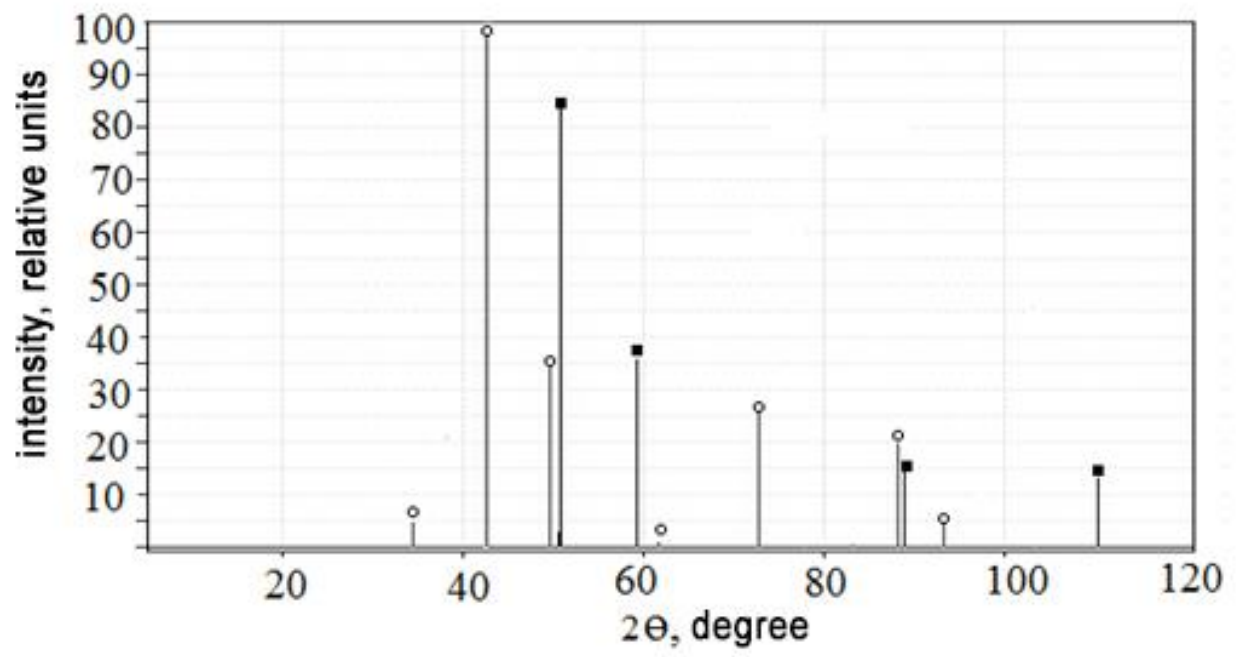

Fig. 1. Line $\mathrm{X}$-ray diffraction pattern of sample $\# 5$ : $\circ-\mathrm{Cu}_{2} \mathrm{O}, \mathbf{\square}-\mathrm{Cu}^{0}$.

The TG curve indicates no change in mass in the temperature range of $\sim 80-160{ }^{\circ} \mathrm{C}$, a small increase in mass in the range $160-360^{\circ} \mathrm{C}$, and a slightly more intense increase at $360-560{ }^{\circ} \mathrm{C}$. 


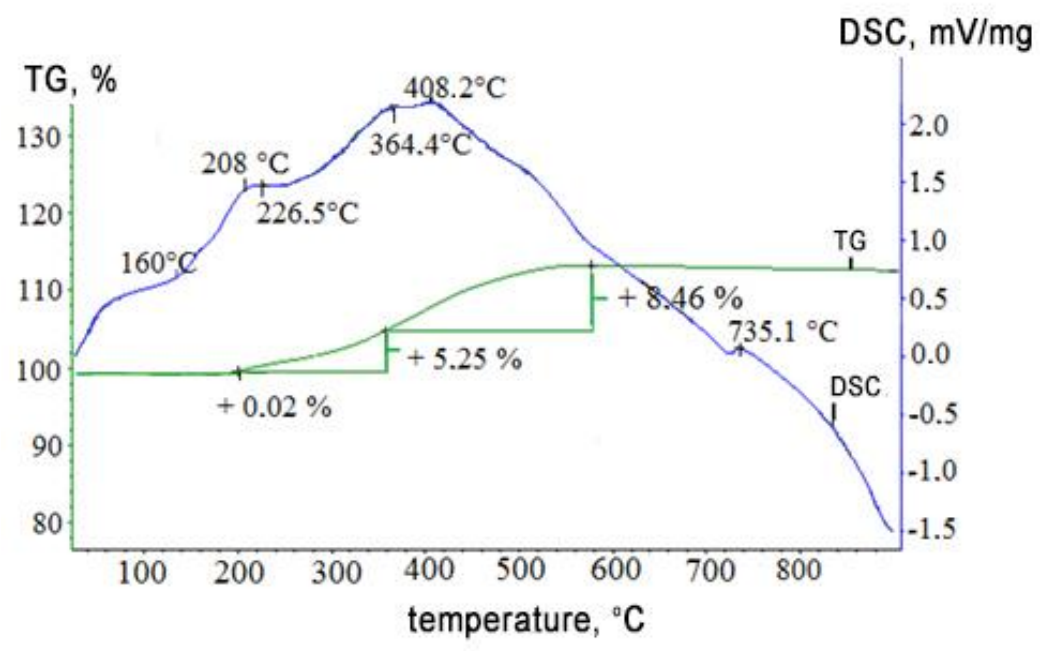

Fig. 2. TG and DSC curves of sample \#5 in air atmosphere.

It may be due to the oxidation of $\mathrm{Cu}$ and $\mathrm{Cu}_{2} \mathrm{O}$ to $\mathrm{CuO}$. The peaks observed on the DSC curve may indicate a stepwise oxidation process. The shape of the DSC curve helped to justify the choice of heating temperatures for the samples (see Table 1). So, the $160-215{ }^{\circ} \mathrm{C}$ interval corresponds to intensive oxidation of copper in the pigment sample, and $260{ }^{\circ} \mathrm{C}$ corresponds to the beginning of the second peak of intense oxidation.

On the DSC curve in a nitrogen atmosphere, no obvious exo- and endo-effects were observed, and on the TG curve, a small ( $3.0 \%$ ) weight loss of the sample is observed, which corresponds to the removal of crystallization water from titanium phosphate. No oxidation of copper compounds occurs.

Based on the results of the experiments, a pigment sample heated at a temperature of $260{ }^{\circ} \mathrm{C}$ with a maximum content of copper (I) oxide $\mathrm{Cu}_{2} \mathrm{O}$ (99.6\%) was selected for further studies (sample \#5).

The most important characteristics of pigments are their uniformity and degree of dispersion. Therefore, the morphology of the obtained powders was evaluated. According to the SEM data of sample \#5 (see Table 1) heated at $260{ }^{\circ} \mathrm{C}$, its surface is uniform, with particle sizes around 0.5 $1 \mu \mathrm{m}$ (Fig. 3). This dispersion of the pigments is an important characteristic, indicating that the material does not require further grinding. 


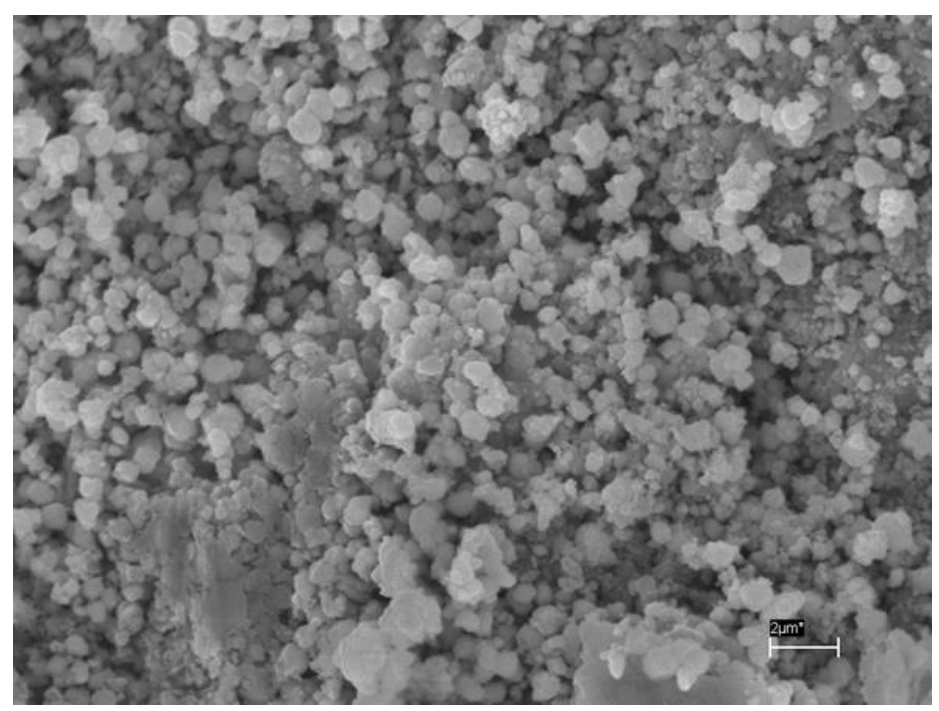

Fig. 3. SEM-image of the sample $\# 5$, heated at $260{ }^{\circ} \mathrm{C}$ with $99,6 \%$ copper (I) oxide content.

For further study of the properties of pigments, experiments were carried out on the leaching of copper ions and phosphate ions from pigment samples obtained at room temperature (sample \#5A) and with heat treatment at temperatures: $160{ }^{\circ} \mathrm{C}$ (sample \#5B), $215{ }^{\circ} \mathrm{C}$ (sample \#5C), and $260{ }^{\circ} \mathrm{C}$ (sample \#5D), in distilled water and water similar in composition to sea water.

The $\mathrm{pH}$ values of the obtained solutions were determined during the leaching process. From table 2 it follows that the concentration of copper ions after leaching in water similar in composition to sea water is significantly higher than in distilled water, and for pigment samples heated at $160-260{ }^{\circ} \mathrm{C}$, 155.6 - $209.9 \mathrm{mg} / \mathrm{dm}^{3}$ respectively. It should be noted that the leachability of copper ions is quite high. The concentration of phosphate ions in leaching solutions for an unheated sample and samples obtained during heating decreases with an increase in the processing temperature from 33.0 to $0.0 \mathrm{mg} / \mathrm{dm}^{3}$. The obtained leaching solutions are weakly acidic with similar $\mathrm{pH}$ values in the range of 4.3-4.8.

Table 2. Concentration of copper and phosphate ions after leaching for 7 days

\begin{tabular}{|c|c|c|c|c|c|c|}
\hline $\begin{array}{c}\text { Sample \#, } \\
\text { solvent }\end{array}$ & $\begin{array}{l}\text { Temperat } \\
\text { ure of } \\
\text { treatment, } \\
{ }^{\circ} \mathrm{C} \\
\end{array}$ & $\begin{array}{c}\text { Initial } \\
\text { pigment } \\
\text { composition }\end{array}$ & $\begin{array}{c}\text { Content of } \\
\text { component } \\
\text { in pigment, } \\
\%\end{array}$ & $\begin{array}{c}\mathrm{Cu}(\mathrm{II}) \text { ions } \\
\text { concentration } \\
\text { in solution, } \\
\mathrm{mg} / \mathrm{dm}^{3}\end{array}$ & $\begin{array}{c}\mathrm{PO}_{4}{ }^{3-} \text { ions } \\
\text { concentration, } \\
\mathrm{mg} / \mathrm{dm}^{3}\end{array}$ & $\mathrm{pH}$ \\
\hline $\begin{array}{l}\# 5 \mathrm{~A}, \\
\text { dist. water }\end{array}$ & 20 & $\begin{array}{l}\mathrm{Cu}_{2} \mathrm{O} \\
\mathrm{Cu} \\
\end{array}$ & $\begin{array}{l}56.4 \\
43.6 \\
\end{array}$ & 89.1 & 28.0 & 4.5 \\
\hline $\begin{array}{l}\text { \#5B, } \\
\text { dist. water }\end{array}$ & 160 & $\begin{array}{l}\mathrm{Cu}_{2} \mathrm{O} \\
\mathrm{Cu}\end{array}$ & $\begin{array}{l}60.5 \\
39.5 \\
\end{array}$ & 94.8 & 24.0 & 4.7 \\
\hline $\begin{array}{l}\# 5 \mathrm{C} \text {, } \\
\text { dist. water }\end{array}$ & 215 & $\begin{array}{l}\mathrm{Cu}_{2} \mathrm{O} \\
\mathrm{Cu} \\
\end{array}$ & $\begin{array}{l}81.4 \\
18.6 \\
\end{array}$ & 111.3 & 19.5 & 4.7 \\
\hline $\begin{array}{l}\text { \#5D, } \\
\text { dist. water }\end{array}$ & 260 & $\begin{array}{l}\mathrm{Cu}_{2} \mathrm{O} \\
\mathrm{CuO} \\
\end{array}$ & $\begin{array}{c}99.6 \\
0.4 \\
\end{array}$ & 118.0 & 0.1 & 4.8 \\
\hline $\begin{array}{l}\# 5 \mathrm{~A}, \\
\text { salt. water }\end{array}$ & 20 & $\begin{array}{l}\mathrm{Cu}_{2} \mathrm{O} \\
\mathrm{Cu}\end{array}$ & $\begin{array}{l}56.4 \\
43.6 \\
\end{array}$ & 155.6 & 33.0 & 4.4 \\
\hline
\end{tabular}


Table 2. Concentration of copper and phosphate ions after leaching for 7 days (continuation)

\begin{tabular}{|l|c|l|c|c|c|c|}
\hline $\begin{array}{l}\text { \#5B, } \\
\text { salt. water }\end{array}$ & 160 & $\begin{array}{l}\mathrm{Cu}_{2} \mathrm{O} \\
\mathrm{Cu}\end{array}$ & $\begin{array}{l}60.5 \\
39.5\end{array}$ & 184.0 & 28.5 & 4.7 \\
\hline $\begin{array}{l}\text { \#5C, } \\
\text { salt. water }\end{array}$ & 215 & $\begin{array}{l}\mathrm{Cu}_{2} \mathrm{O} \\
\mathrm{Cu}\end{array}$ & $\begin{array}{l}81.4 \\
18.6\end{array}$ & 205.6 & 23.5 & 4.5 \\
\hline $\begin{array}{l}\text { \#5D, } \\
\text { salt. water }\end{array}$ & 260 & $\begin{array}{l}\mathrm{Cu}_{2} \mathrm{O} \\
\mathrm{CuO}\end{array}$ & $\begin{array}{l}99.6 \\
0.4\end{array}$ & 210.0 & 0.0 & 4.3 \\
\hline
\end{tabular}

Evaluation tests of the biocidal activity of the obtained pigments in relation to ciliates Tetrachimena piriformis and test cultures of bacteria Staphylococcus aureus, Bacillus subtilis were carried out. Table 3 shows the number of multiplied protozoa Tetrachimena piriformis in the sample when pigments \#5A, 5B, 5C, 5D are added to the culture medium. Samples containing a medium with infusoria without adding a weighed portion of pigment served as control for the analysis.

Table 3. Toxicity of pigment samples to Tetrachimena piriformis ciliates

\begin{tabular}{|c|c|c|c|c|}
\hline \multirow{2}{*}{ Sample } & \multicolumn{4}{|c|}{ Number of ciliates } \\
\cline { 2 - 5 } & $1 \mathrm{~h}$ & $6 \mathrm{~h}$ & $24 \mathrm{~h}$ & $96 \mathrm{~h}$ \\
\hline Sample \#5A & - & - & - & 40 \\
\hline Sample \#5B & - & - & - & 60 \\
\hline Sample \#5C & - & - & 1 & 80 \\
\hline Sample \#5D & - & - & 6 & 120 \\
\hline Control sample & 15 & 40 & 60 & 140 \\
\hline
\end{tabular}

As it can be seen from the table 3, there was no growth of ciliates during the day in the medium with samples $5 \mathrm{~A}$ and $5 \mathrm{~B}$, in the medium with sample $5 \mathrm{C}$ one ciliate was observed in the field of view, with sample 5D - 6 ciliates. When ciliates were cultivated at a temperature of $25^{\circ} \mathrm{C}$ for $96 \mathrm{~h}$, the growth of ciliates was observed in all samples. However, in samples $5 \mathrm{~A}$ and $5 \mathrm{~B}$ the degree of reproduction of ciliates is less than in the control sample by $71.4 \%$ and $57.1 \%$, respectively, which indicates a strong toxicity (4 points). In the sample $5 \mathrm{C}$, the decrease in the degree of reproduction of ciliates in relation to the control sample was $42.9 \%$, which corresponds to pronounced toxicity (3 points). A decrease in the degree of reproduction of ciliates in the sample 5D in relation to the control sample by $14.3 \%$ indicates weak toxicity (1 point).

When studying the resistance of the test microbes Staphylococcus aureus, Bacillus subtilis to the obtained samples of pigments by diffusion into agar using wells in the thickness of the agar, it was found that all samples formed a zone of inhibition of microbial growth (lysis) both on the culture of Bacillus subtilis and on the culture of Staphylococcus aureus (excl. sample 5A), above $15 \mathrm{~mm}$, which indicates a good bacteriostatic activity of the samples to these test cultures (Table 4). 
Table 4. Results of studying the bacteriostatic properties of pigment samples in relation to test cultures of bacteria Staphylococcus aureus, Bacillus subtilis

\begin{tabular}{|l|c|c|}
\hline \multirow{2}{*}{\multicolumn{1}{|c|}{ Sample }} & \multicolumn{2}{c|}{ Size of lysed zone for bacteria, mm } \\
\cline { 2 - 3 } & Staphylococcus aureus & Bacillus subtilis \\
\hline Sample \# 5A & 13 & 23 \\
\hline Sample \# 5B & 20 & 16 \\
\hline Sample \# 5C & 18 & 22 \\
\hline Sample \# 5D & 19 & 17 \\
\hline Medium control & \multicolumn{2}{|c|}{ No growth } \\
\hline
\end{tabular}

\section{Conclusions}

A method is proposed for obtaining pigments with a toxic effect on marine microorganisms, based on titanium (IV) phosphate and copper oxide using redox transformations in solutions containing $\mathrm{CuCl}_{2}$ and trivalent titanium phosphate, for use in coatings that prevent biofouling of ship hulls in sea water.

It is shown that by varying the initial molar ratio of $\mathrm{Cu}$ (II) : $\mathrm{Ti}$ (III) in the composition of the pigment, the order of mixing the solutions, and the temperature of heat treatment of the pigment, it is possible to change the ratio of various copper compounds in the polymer matrix of titanium phosphate. It was found that with an increase in this ratio in the samples obtained, the mass fraction of copper (I) oxide increases and the fraction of elemental copper decreases.

The conditions for obtaining a pigment with a maximum content of copper (I) oxide, necessary for prolonged inhibition of fouling, were found. Such a pigment is obtained with an initial ratio of $\mathrm{Cu}$ (II) : Ti (III) components equal to 4.5 and a heat treatment temperature of $260{ }^{\circ} \mathrm{C}$. The $\mathrm{Cu}_{2} \mathrm{O}$ content in it is $99.6 \%$, the particles have sizes around $0.5-1 \mu \mathrm{m}$. The material does not require further grinding.

The ability of the compositions to leach copper ions and phosphate ions in distilled water and in water similar in composition to seawater, depending on the conditions of heat treatment, was studied. It has been shown that the concentration of copper ions in water similar in composition to seawater is significantly higher than in distilled water and is $155.6-209.9 \mathrm{mg} / \mathrm{dm}^{3}$ for pigment samples heated at $160-260{ }^{\circ} \mathrm{C}$, respectively.

Evaluation tests of the biocidal activity of the obtained pigments in relation to ciliates Tetrachimena piriformis and test cultures of bacteria Staphylococcus aureus, Bacillus subtilis were carried out. It is shown that the samples obtained by the proposed method have high biocidal activity.

\section{Conflict of interests}

The authors declare that they have no conflict of interest. 


\section{References}

Baxter, K. F. Marine anti-fouling paint. US Patent 4675051, July 23, 1987.

Beznosov, V. N.; Suzdaleva, A. L.; Minin, D. V. [i dr.] Mnogoslojnoe kombinirovannoe protivoobrastayushchee pokrytie, obespechivayushchee repellentno-hemobiocidnuyu zashchitu. RU Patent 2478114, March 27, 2013. [in Russian]

Braeken, J.; Dererk, J. P.; Poel, H. [et al.] Self polishing anti-fouling paints. US Patent 4962135, October 9, 1990.

Camp, D.; Zawacky, S. Anti-fouling coatings containing silica-coated copper. US Patent 7147921, October 7, 2004.

Gurevich, E. S.; Izral'yanc, E. D. Neobrastayushchaya kraska. SU Patent 273905, April 15, 1983. [in Russian]

Gurevich, E. S.; Ruhadze, E. G.; Frost, A. E. [i dr.] Zashchita ot obrastaniya; Nauka: Moscow, 1989. [in Russian]

Karpov, V. A., Drinberg, A. S.; Icko, E. F. Sposob polucheniya protivoobrastayushchej email. RU Patent 2394864, July 20, 2010. [in Russian]

Kopylov, N. I.; Kaminskij, Yu. D.; Lyahov, N. Z. Biocid dlya protivoobrastayushchego pokrytiya. RU Patent 2433154, November10, 2011. [in Russian]

Maslova, M. V.; Gerasimova, L. G.; Ohrimenko, R. F. [i dr.] Zhurn. prikl. himii. 2006, 79 (11), 1813-1817. [in Russian]

Matsuo, T.; Doi, H. Antifouling paint containing polymer of ethylenically unsaturated organotin monomer. US Patent 4914141, April 3, 1990.

Railkin, A. I. Colonization processes and protection against bio-fouling; St. Petersburg University: St. Petersburg, 1998. [in Russian]

Sarawadekar, R. G.; Kulkarni, S. B. Thermochimica Acta. 1983. 67, 341-349.

Shablovski, V.A. Vliyanie gidrotermal'noj obrabotki na fiziko-himicheskie svojstva sorbentov na osnove fosfatov metallov IV V gruppy, Ph.D. Thesis, Belarussian State University, Minsk, 1983. [in Russian]

Sheshukov, A.,V.; Simanovich, M. B.; Icko E. F. [i dr.] Lakokrasochnye materialy i ih primenenie. 1992, 5, 47-51. [in Russian]

ZAO «HIMEKO-GANG». Protivoobrastayushchaya i antikorrozionnaya kraska. RU Patent 2115680, July 20, 1998. [in Russian]

Zobachev, D. E.; Sominskij, E. V. Zashchita sudov ot korrozii i obrastaniya; Transport: Moscow, 1984. [in Russian] 


\title{
ЗАХИСТ КОРПУСІВ СУДЕН Ті, Сu - БІОЦИДНИМИ ПІГМЕНТАМИ
}

\author{
${ }^{1}$ В. О. Шабловський, ${ }^{1}$ А. В. Тучковська, ${ }^{1}$ В. А. Рухля, ${ }^{1}$ О. Г. Пап, ${ }^{2}{ }^{*}$ С. Л. Василюк
}

${ }^{1}$ Лабораторія неорганічних сорбентів i антикорозійних покриттів, Науково-дослідний інститут фізико-хімічних проблем Білоруського державного університету (НДІ ФХП БГУ), Мінськ, 220006, Беларусь.

${ }^{2}$ Спеціальне кострукторсько-технологічне бюро 3 дослідним виробництвом Інституту загальної та неорганічної хімії ім. В. І. Вернадського НАН України, Київ, 03142, Україна.

*Автор для листування: vasiluk@ionc.kiev.ua

\section{Реферат}

Основні напрямки створення нових форм протиобростаючих покриттів корпусів морських суден лежать в області отримання оптимального біоциду або суміші біоцидів. В якості основного біоциду в таких композиціях в даний час використовують оксид міді (I) i мідьвмисні сполуки. Для отримання конкурентоспроможних біоцидів, що містять оксид міді (I), необхідно використовувати відносно дешеві інертні наповнювачі. Авторами запропонований метод отримання пігментів на основі фосфату титану (IV) із сполуками міді, що володіють токсичною дією по відношенню до морських мікроорганізмів, для використання в складі покриттів, що перешкоджають біообростанню корпусів суден в морській воді. Показано, що, варіюючи вихідне співвідношення $\mathrm{Cu}$ (II) : Ti (III) в складі пігменту, порядок змішування розчинів і температуру термообробки пігменту, можна змінювати зміст різних сполук міді в полімерній матриці фосфату титану. Отримані зразки були вивчені за допомогою рентгенографічного методу, методу диференціальної скануючої калориметрії, СЕМ та інших. Методом термічного синхронного аналізу в повітряній атмосфері і атмосфері азоту вивчені термічні перетворення зразків фосфату титану (IV), що містять мідь в різному ступені окислення.

Знайдено умови отримання пігменту з максимальним вмістом оксиду міді (I), необхідні для пролонгованого гальмування обростання. Вивчено здатність композицій до вилуговування іонів міді і фосфат-іонів в дистильованої воді і в воді, близької за складом до морської залежно від умов термообробки. Проведено оціночні випробування біоцидною активності отриманих пігментів по відношенню до інфузорій Tetrachimena piriformis і тест-культур бактерій Staphylococcus aureus, Bacillus subtilis.

Ключові слова: протиобрастаючі пігменти; біоцидні властивості; фосфат титану; сполуки міді (I) $i$ (II). 